\title{
High single-cell metabolic activity in Antarctic sea ice bacteria
}

\author{
Andrew Martin ${ }^{1, *}$, Julie A. Hall ${ }^{2}$, Ronan O'Toole ${ }^{1}$, Simon K. Davy ${ }^{1}$, Ken G. Ryan ${ }^{1}$ \\ ${ }^{1}$ Victoria University of Wellington, PO Box 600, Wellington 6140, New Zealand \\ ${ }^{2}$ National Institute of Water and Atmospheric Research, PO Box 11-115, Hamilton 3216, New Zealand
}

\begin{abstract}
Antarctic sea ice bacteria have historically been examined by techniques that measure bulk community properties. In recognition of the complexity of microbial community structure and function, methods are now available to assess the physiological status of individual bacterial cells. We employed 3 assays: Nucleic Acid Double Staining (NADS), modified Vital Stain and Probe (mVSP) and 5-cyano-2,3-ditolyl tetrazolium chloride (CTC) to (1) quantify the cell-specific metabolic status of bacteria present in the bottom of Antarctic fast-ice and (2) determine whether physiological probes can be used to quantify short-term changes in bacterial metabolic activity. Each assay was used in manipulative experiments $(<8 \mathrm{~h})$ conducted on bacteria from melted ice cores with dark/light $(5 \mu \mathrm{mol}$ photons $\mathrm{m}^{-2} \mathrm{~s}^{-1}$ ) and the presence/absence of microalgae (filtered, unfiltered samples) as treatment variables. Estimates of cell viability (intact membranes) were $>68 \%$ (NADS) and $>95 \%$ (mVSP) of the post-incubation cell count. High cellular rRNA content was observed using fluorescence in situ hybridisation with an average of $80 \%$ of DAPI-stained cells hybridising with the general bacterial probe EUB338 (mVSP). An average of $32 \%$ of the bacterial cells were undergoing active respiration (CTC+) which is significantly higher than the 2 to $10 \%$ level of activity typical for most marine systems. The short-term effect of incubation irradiance or manipulation of microalgal photosynthate was not significant for any assay. Single-cell analysis of melted ice cores suggests that sea ice is among the most productive microbial habitats, while CTC is favoured for establishing a real-time bacterial response in the sea ice ecosystem.
\end{abstract}

KEY WORDS: Sea ice bacteria $\cdot$ Antarctica $\cdot$ Activity $\cdot$ Viability $\cdot$ Physiological probes

\section{INTRODUCTION}

While bacteria are now recognised as a major biological force in the oceanic carbon cycle and ecosystem structure (Delille 1996, Azam \& Worden 2004), our understanding of the diversity and functional capabilities of bacteria in Antarctic sea ice remains fragmentary. There is, however, increasing evidence to suggest that bacterial communities play an ecologically important role in Antarctic ice-covered marine regions (Garrison et al. 2005). As sea ice forms, dissolved salts are excluded from the freshwater ice matrix and microbes become concentrated in microscopic pockets of liquid brine within the ice. Estimates of the seasonal abundance of bacteria in both fast- and pack-ice environments, coupled with measurements of biomass production, have led several authors to propose an active microbial loop operating within sea ice which is similar in function to that of temperate marine systems (Sullivan \& Palmisano 1984, Azam et al. 1991). However, the links between the growth and production rates of bacteria with higher trophic levels in the microbial loop have yet to be clearly defined. Bacterial assimilation of dissolved organic matter (DOM) is a core process in the microbial loop hypothesis (Azam et al. 1991), but remains equivocal with respect to the spatial and 
temporal variability of the sea ice ecosystem (Stewart \& Fritsen 2004).

To understand the ecology of microbial communities, information about the identity and metabolic activity of individual microbes is needed (Sherr et al. 1999). A variety of stains and probes are now available that provide insight into the level of single-cell activity; these techniques target a number of properties associated with cellular physiology such as membrane integrity, specific enzyme activity, ribosomal RNA content and cellular reducing potential (Howard-Jones et al. 2001). Single-cell analyses provide a high degree of experimental resolution, but there is currently no consensus regarding the validity of these methods (Smith \& del Giorgio 2003), or even which are the most reliable (Joux \& Lebaron 2000, Howard-Jones et al. 2001, Davidson et al. 2004). Importantly, it is becoming evident that bacterial communities can exhibit a range of physiological states including viable non-culturable, dormant and active. In light of this, Smith \& del Giorgio (2003) have suggested that only a combination of methods will effectively describe community metabolic activity.

This study is the first to examine single-cell metabolic activity in Antarctic sea ice bacteria using a range of protocols. We examine membrane integrity (Nucleic Acid Double Staining [NADS] and modified Vital Stain and Probe [mVSP]), ribosomal RNA content (mVSP), and cellular respiration (5-cyano-2,3-ditolyl tetrazolium chloride [CTC]) to determine the cell-specific metabolic status of Antarctic sea ice bacteria. Specifically, we (1) assess bacterial metabolic activity of cells present in the bottom community of Antarctic fast-ice and (2) determine whether physiological probes can be used to quantify potential changes in bacterial metabolic activity during short-term manipulative experiments.

\section{MATERIALS AND METHODS}

Study site. Sea ice bacteria and algae were collected in November 2004 from fast-ice ca. $1.5 \mathrm{~m}$ thick at Cape Hallett, Antarctica $\left(72^{\circ} 19^{\prime} \mathrm{S}, 170^{\circ} 13^{\prime} \mathrm{E}\right)$. A series of holes $(<1.2 \mathrm{~m})$ were drilled in close proximity with a powered ice auger (Jiffy) and cores (200 to $300 \mathrm{~mm}$ long, $130 \mathrm{~mm}$ diameter) were extracted from the bottom of each profile using a Kovaks ice corer. To minimise light shock, all operations were performed under a black sheet and each core was transported in a black plastic tube. Bottom ice bacterial and algal cells were obtained by cutting off the bottom $50 \mathrm{~mm}$ of each core and melting this into 3 times the quantity of $0.22 \mu \mathrm{m}$ filtered seawater $\left(35 \%,-1.8^{\circ} \mathrm{C}\right)$, under low light $\left(<1 \mu \mathrm{mol}\right.$ photons $\left.\mathrm{m}^{-2} \mathrm{~s}^{-1}\right)$, in sterile containers over a period of $12 \mathrm{~h}$ (following the procedures in Ryan et al. 2004). Throughout the melting process cells remained at $-1.8^{\circ} \mathrm{C}$ as the process of ice melt maintains the temperature equilibrium. For each experiment, the cells from 3 to 4 melted cores were combined in a single container with a typical final volume of $500 \mathrm{ml}$. To remove the majority of microalgal cells (typically 10 to $100 \mu \mathrm{m}$ for sea ice algae) for the filtered treatment, ca. $250 \mathrm{ml}$ of the initial stock was passed through a series of filters, 2 filter nets $(50 \mu \mathrm{m}$ and $5 \mu \mathrm{m})$ followed by vacuum filtration with a $3 \mu \mathrm{m}$ filter (Millipore).

Incubations were performed in a water bath maintained at $-1.8^{\circ} \mathrm{C}$. An ethanol:water (1:4) mix was used in the bathing solution to provide subzero temperatures, and a heater stirrer was used to maintain the incubator to within $\pm 0.2^{\circ} \mathrm{C}$. During incubations, samples were assigned to either a light ( $5 \mu \mathrm{mol}$ photons $\mathrm{m}^{-2} \mathrm{~s}^{-1}$ ) or dark treatment and 2 algal cell concentrations, filtered or unfiltered.

mVSP. The mVSP assay developed by HowardJones et al. (2002) was used to detect cellular ribosomal content using fluorescence in situ hybridisation (FISH) with a 16S rRNA-targeted oligonucleotide probe specific for eubacteria, while simultaneously examining membrane integrity. Samples $(15 \mathrm{ml})$ were incubated for a period of $7 \mathrm{~h}$ (to observe possible changes in membrane integrity) at $-1.8 \pm 0.2^{\circ} \mathrm{C}$ in $20 \mathrm{ml}$ glass vials. Samples were then mixed with $5 \mathrm{ml}$ of sterile $99 \%$ glycerol (25\% final concentration), acclimated for $15 \mathrm{~min}$ to allow for subsequent storage and frozen at $-20^{\circ} \mathrm{C}$. On return to Victoria University of Wellington (VUW) samples were thawed to room temperature. One ml was extracted from each sample, fixed with methanol ( $2 \%$ final concentration) and incubated for 30 min (in the dark at ambient temperature) in order to stabilise cell membranes. Cells were then simultaneously stained with DAPI (final concentration $3 \mu \mathrm{g} \mathrm{ml}^{-1}$ ) and PI (final concentration $0.2 \mu \mathrm{g} \mathrm{m}^{-1}$ ) and incubated for $30 \mathrm{~min}$ (in the dark at ambient temperature). To permeabilise/dehydrate the cells, $200 \mu$ of ethanol/ formaldehyde (90:10 v/v) was added before incubating for a further $30 \mathrm{~min}$ (in the dark, $\pm 2^{\circ} \mathrm{C}$ of ambient). Samples were then filtered onto $0.22 \mu \mathrm{m}$ black polycarbonate filters backed with $25 \mathrm{~mm} \mathrm{GF/F} \mathrm{filters} \mathrm{and}$ washed several times with $1 \mathrm{ml}$ aliquots of $10 \mathrm{mM}$ $\mathrm{MgSO}_{4}$. Each filter was carefully overlaid with a hybridisation solution $(0.2 \% \mathrm{w} / \mathrm{v}$ bovine serum albu$\min [\mathrm{BSA}], 0.01 \% \mathrm{w} / \mathrm{v}$ polyadenylic acid, $1 \times \mathrm{SET}$ [150 mM NaCl, 20 nm Tris-HCl, 1 mM EDTA, pH = 8.0] and $11 \%$ dextran sulfate) containing $340 \mathrm{ng}$ of probe. The oligonucleotide probe used in the present study was Primer EUB338 (5'gctgcctcccgtaggagt) modified with a 5' amino terminus and linked with the flurochrome Alexa Fluor 488 (Molecular Probes). In the original protocol of Howard-Jones et al. (2002) 3 
probes were utilised, but following consultation with the authors, a single probe was deemed adequate. Slides were hybridised overnight at $37^{\circ} \mathrm{C}$ in a humidified chamber, then washed for $30 \mathrm{~min}$ in 3 changes of $1 \times \mathrm{SET}$, air-dried and mounted with VectorShield antifade. For each slide 200 to 300 cells were observed and total cells (DAPI), dead cells (PI) and active cells (probe positive) were enumerated using Wide UV, Wide Green and Narrow Blue filter sets, respectively, on an Olympus Provis AX70 microscope.

NADS. Samples initially collected for use with the mVSP assay were also analysed using the double staining protocol calibrated for marine systems by Grégori et al. (2001). From each of the thawed $15 \mathrm{ml}$ glycerol-treated samples, a further $500 \mu$ of each sample was simultaneously stained with 1:1000 (vol/vol) SYBR Green II (Molecular Probes) and PI (final concentration $15 \mu \mathrm{g} \mathrm{ml}^{-1}$ ) for $30 \mathrm{~min}$ (in the dark at ambient temperature). Samples were then analysed on a Becton Dickinson FACScan flow cytometer equipped with a $15 \mathrm{~mW}$, $488 \mathrm{~nm}$, air-cooled argon ion laser and standard filter setup. Initial instrument calibration was performed using FACScomp software in conjunction with Becton Dickinson CaliBRITE reference beads. To avoid coincidence, samples were run on a medium flow rate with less than 1300 events $\mathrm{s}^{-1}$. Each sample was run for 1 min. Becton Dickinson CellQuest software was used for all sample and data analyses. Bacterial cell populations were identified from bivariate plots of green (FL1) vs. red (FL3) fluorescence to highlight cells stained with SYBR Green II (live) and PI (damaged, dead), respectively.

To determine the impact of freezing and glycerol storage on the abundance of live and damaged cells, a test was carried out at VUW using the NADS assay. Both intact and membrane-compromised Escherichia coli cells were added to $15 \mathrm{ml}$ of $0.22 \mu \mathrm{m}$ filtered seawater and then mixed with $5 \mathrm{ml}$ of sterile $99 \%$ glycerol (25\% final concentration). Following a 15 min acclimation period, each sample was stained and analysed as detailed above. The samples were then frozen at $-20^{\circ} \mathrm{C}$ and reanalysed using the NADS assay 2 wk later.

CTC. Intracellular reduction was examined using CTC. Samples $(900 \mu \mathrm{l})$ were prepared in $1 \mathrm{ml}$ Eppendorf tubes and maintained at $-1.8 \pm 0.2^{\circ} \mathrm{C}$ in the water bath for $4 \mathrm{~h}$. CTC (100 $\mu \mathrm{l})$ was then added to each sample (5 mM final concentration) before being returned to the water bath for a further $3 \mathrm{~h}$. The incubation temperature was maintained at $-1.8 \pm 0.2^{\circ} \mathrm{C}$ for the second incubation phase, but samples were not exposed to light. Three blank samples consisting of $0.22 \mu \mathrm{m}$ filtered, double-distilled water and CTC were incubated under the same conditions described above to control for non-specific signals (i.e. CTC precipitate). Sample incubation was terminated with the addition of $50 \mu$ of
$0.22 \mu \mathrm{m}$ filtered formalin (5\% final concentration), and all samples were immediately frozen in liquid nitrogen (Sherr et al. 1999). CTC-treated samples were transported at $-80^{\circ} \mathrm{C}$ and kept frozen until analysed. Enumeration of CTC+ and total bacterial cells was performed using a Becton Dickinson FACScan flow cytometer (details as described earlier). TruCount beads (Beckton Dickinson) were added to each sample in order to accurately calculate the volume of sample analysed. Bacterial data were typically collected for 3 min (acquisition of 200 TruCount beads), and CTC+ positive cells were identified from bivariate plots of red (FL3) vs. orange (FL2) fluorescence. Total bacterial counts were determined by rerunning each sample following a $10 \mathrm{~min}$ incubation with SYBR Green II (Molecular Probes) and examining bivariate plots of green (FL1) fluorescence vs. SSC (Side Scatter).

Statistical analysis. For each assay a 2-way analysis of variance (ANOVA) was used to test for main effects of light and treatment regimes using SYSTAT (Version 7.0, SPSS). To determine the effects of glycerol fixation and storage in the NADS control experiment, a paired Student's $t$-test was used to compare the percentage of membrane-compromised cells (PI-stained) as a fraction of the total cell count (SYBR II-stained).

\section{RESULTS}

Of the bacterial cells examined using the NADS assay, ca. $70 \%$ had intact cell membranes and stained only with the SYBR Green II dye component (Table 1). All remaining cells were double stained and deemed to be 'leaky' (stained with both SYBR Green II and PI), while the number of fully compromised cells (stained with PI only) was negligible. Determining the relative proportions of intact or leaky bacterial cells by flow cytometry was straightforward using cytograms of red (FL3) vs. green (FL1) fluorescence. In the separate control experiment there was no significant difference in the percentage of PI-stained cells between fresh and frozen samples using the NADS assay which indicates that freezing and glycerol storage had no effect on the staining regime $(t=-1.31, \mathrm{df}=2, \mathrm{p}=0.321, \mathrm{n}=3)$.

Competition for binding sites using the DAPI/PI component of the mVSP assay revealed significantly fewer compromised or 'leaky' cells compared to the NADS assay. Microscopic counts revealed that the majority of bacterial cells had intact cell membranes (Table 1) with DAPI-stained cells accounting for $>95 \%$ of the total cell counts.

High intracellular activity was observed with the FISH component of the mVSP protocol. Cells with sufficient numbers of ribosomes to be detected by probe hybridisation and visualised using a Narrow Blue filter 
Table 1. Post-incubation estimates of cell membrane integrity/intracellular activity for Antarctic bottom-ice bacteria collected at Cape Hallett with dark/light $\left(5 \mu \mathrm{mol}\right.$ photons $\left.\mathrm{m}^{-2} \mathrm{~s}^{-1}\right)$ and presence/absence (filtered, unfiltered) of microalgae as treatment variables. NADS (nucleic acid double staining); mVSP (modified vital stain and probe); CTC (5-cyano-2,3-ditolyl tetrazolium chloride). Data are means $\pm 1 \mathrm{SE}$

\begin{tabular}{|c|c|c|c|c|c|c|c|}
\hline \multirow[t]{3}{*}{ Assay } & \multirow[t]{3}{*}{ Irradiance } & \multicolumn{6}{|c|}{ Treatment } \\
\hline & & \multicolumn{3}{|c|}{ _ Unfiltered _ } & \multirow{2}{*}{\multicolumn{2}{|c|}{$\begin{array}{l}\text { Filtered } \\
\text { Damaged cells }\end{array}$}} & \multirow{2}{*}{$\%$ intact } \\
\hline & & Intact cells I & Damaged cells & $\%$ intact & & & \\
\hline \multirow{2}{*}{$\begin{array}{l}\text { NADS } \\
\text { (Cell counts) }\end{array}$} & Dark & $14420( \pm 1577)$ & $5917( \pm 98)$ & 71 & $2103( \pm 411)$ & $848( \pm 56)$ & 71 \\
\hline & $5 \mu \mathrm{mol}$ photons $\mathrm{m}^{-2} \mathrm{~s}^{-1}$ & $13244( \pm 1139)$ & $5839( \pm 86)$ & 69 & $1871( \pm 302)$ & $776( \pm 153)$ & 71 \\
\hline \multirow{4}{*}{$\begin{array}{l}\text { mVSP } \\
\text { (\% intact) } \\
\text { (\% probe } \\
\text { positive) }\end{array}$} & Dark & $>95 \%$ & & & $>95 \%$ & & \\
\hline & $5 \mu \mathrm{mol}$ photons $\mathrm{m}^{-2} \mathrm{~s}^{-1}$ & $>95 \%$ & & & $>95 \%$ & & \\
\hline & Dark & $79( \pm 5)$ & & & $86( \pm 5)$ & & \\
\hline & $5 \mu \mathrm{mol}$ photons $\mathrm{m}^{-2} \mathrm{~s}^{-1}$ & $66( \pm 25)$ & & & $92( \pm 5)$ & & \\
\hline \multirow{2}{*}{$\begin{array}{l}\text { CTC } \\
\text { (\% respiring) }\end{array}$} & Dark & $32( \pm 1)$ & & & $30( \pm 7)$ & & \\
\hline & $5 \mu \mathrm{mol}$ photons $\mathrm{m}^{-2} \mathrm{~s}^{-1}$ & $32( \pm 3)$ & & & $34( \pm 7)$ & & \\
\hline
\end{tabular}

set accounted for an average of $80 \%$ of the cells examined, inferring significant bacterial activity and growth (Table 1).

The intracellular reduction of CTC to its red-fluorescing insoluble form was recorded in all samples. Of the bacterial cells, ca. $32 \%$ were considered to have an active electron transport system and be undergoing oxidative metabolism (Table 1).

There was no statistically significant difference for any assay between samples cultured in the light (5 $\mu \mathrm{mol}$ photons $\mathrm{m}^{-2} \mathrm{~s}^{-1}$ ) or kept in the dark during the incubation period $(\mathrm{p}=0.69, \mathrm{n}=3$ for NADS $; \mathrm{p}=0.84$, $\mathrm{n}=3$ for $\mathrm{mVSP}$ and $\mathrm{p}=0.70, \mathrm{n}=6$ for CTC). No effect on cell viability or intracellular activity was found in comparing the filtered and unfiltered treatments (presence/absence of microalgae) for any of the 3 assays $(\mathrm{p}=0.81, \mathrm{n}=3$ for NADS; $\mathrm{p}=0.28, \mathrm{n}=3$ for $\mathrm{mVSP}$ and $\mathrm{p}=0.99, \mathrm{n}=6$ for CTC).

\section{DISCUSSION}

Understanding the spatial and temporal dynamics of Antarctic sea ice and associated biotic communities is fundamental to quantifying the trophodynamics of the Antarctic coastal ecosystem. Evidence that bacteria actively grow in sea ice dates back to the 1980s. Sullivan \& Palmisano (1984) observed large and morphologically distinct cells undergoing cell division in fast-ice in McMurdo Sound, implying an active heterotrophic community, while microautoradiographic uptake of radio-labeled compounds such as ${ }^{14} \mathrm{C}$-L-serine, ${ }^{3} \mathrm{H}$-serine, ${ }^{3} \mathrm{H}$-glucose and ${ }^{3} \mathrm{H}$-thymidine confirmed community-level activity in the form of DNA synthesis (Sullivan \& Palmisano 1984, Sullivan et al. 1985). Results presented in the present study provide further evidence that bacteria are highly active within the sea ice matrix during the austral spring. The enhanced res- olution provided by single-cell analysis revealed that $32 \%$ of the cells examined were undergoing active respiration (CTC+) (Table 1$)$. This is a significantly higher fraction than the 2 to $10 \%$ level of activity typical for most marine systems (Bernard et al. 2001, Longnecker et al. 2005). Additionally, high ribosomal content was detected in the majority of cells analysed by fluorescence in situ hybridisation, and a comparable level of viability was inferred in the fraction of bacterial cells with intact membranes (Table1). Given that the methods target different physiological characteristics, a consensus among techniques was not necessarily expected. However, the synthesis of information on membrane integrity, rRNA content and respiratory activity confirms sea ice to be a productive microbial habitat. Although the sample sizes are small, these results suggest that the majority of cells were contributing to secondary production and trophic dynamics at the time of sampling. This high single-cell activity reflects the favourable suite of physicochemical traits associated with bacterial growth and development in the sea ice ecosystem. The total bacterial biomass increases rapidly during the austral summer, particularly in the bottom or congelation layer of fastice, where salinity, temperature, availability of DOM and other nutrient pools result in bacterial carbon concentrations that can be 10 times higher than that of bacterioplankton in the water column below (Sullivan \& Palmisano 1984). Although a novel approach to DAPI staining developed by Junge et al. (2001) now allows the in situ abundance of bacterial cells to be determined in thin sections of ice, melting of the ice matrix is still required to examine metabolic activity. The procedure of Ryan et al. (2004) is currently the best method in approximating in situ sea ice conditions and results in minimal changes in temperature during the melting process. However the release of DOM in particular from the ice matrix has been shown to enhance 
both primary and secondary production (Giesenhagen et al. 1999), and this may have influenced our findings.

Of particular interest is the trophic relationship between bacteria and microalgae, and this has historically been inferred by gross correlations between bacterial and algal biomass (see Stewart \& Fritsen 2004 and references therein). However, few physiological experiments have been conducted that include the bacterial component of the sea ice community (but see Kottmeier \& Sullivan 1988, Nichols et al. 1999). In the present study, restricting the availability of algal photosynthate (DOM) for bacterial uptake by incubating samples in the dark and reducing the volume of algal cells did not restrict bacterial metabolic activity (Table 1.) This implies that photosynthate supply was not a limiting factor for bacterial metabolism during the period of incubation. It is also likely that the process of filtration ruptured algal cells, potentially increasing the availability of DOM in the filtered treatment. Given the observed level of metabolic activity in both treatments we suggest that the samples were saturated with photosynthate and that future experiments would require significantly longer incubation periods to establish an activity threshold. Few studies examine bacterial membrane integrity, and those that have commonly focus on the effect of ultraviolet radiation on permeability over a time period of several days (e.g. Maranger et al. 2002).

The phenanthridinium derivative PI is one of the most common impermeant or 'dead cell stains', but has been used at varying concentrations in the literature (see Davidson et al. 2004). For the viability component of the mVSP, we followed the guidelines of Williams et al. (1998) who developed the protocol and suggested staining at $0.2 \mu \mathrm{g} \mathrm{ml}^{-1}$. Given the low return of PI-stained cells at this concentration $(<1 \%)$, we surveyed the literature before using the NADS protocol and increased the concentration to $15 \mu \mathrm{g} \mathrm{ml}^{-1}$ (based on Grégori et al. 2001, Alonso-Sáez et al. 2006). This increase in PI concentration resulted in a larger $(\sim 30 \%$ of the total) population of 'leaky' or compromised cells that stained with both PI and SYBR Green II. Unlike Grégori et al. (2001) we did not generate cytograms with a distinct population of cells stained with PI only (fully compromised/dead). The increased concentration of PI would suggest a more appropriate staining regime for the samples we obtained, but the results illustrate that the abundance of compromised cells can vary greatly with stain concentration. However, samples stored in glycerol can be stained according to the NADS protocol and be effectively analysed by flow cytometry, which as far as we are aware has not been demonstrated before. Both assays infer high membrane integrity and do not require fixation/rapid processing which provides a distinct advantage given the logistical constraints of deep-field Antarctic research.

During recent years, FISH with rRNA-targeted oligonucleotide probes has been successfully applied to a range of freshwater, coastal and offshore marine ecosystems (Pernthaler et al. 2001). In addition to describing bacterial community structure (e.g. domain or group-specific probing), this method is a sensitive measure of cell-specific activity as the FISH threshold signal is correlated with cellular rRNA content (Howard-Jones et al. 2002, Pernthaler et al. 2002, Junge et al. 2004). In a recent review, Bouvier \& del Giorgio (2003) reported the detection rate of bacterioplankton across a range of aquatic communities using the bacteria-specific probe EUB338 to vary between 5 and $100 \%$. These differences may reflect variations in the physiological status of bacterial cells, but some authors have highlighted limitations relating to methodological differences such as fluorochrome type, stringency conditions and cell type (see Bouvier \& del Giorgio 2003, Smith \& del Giorgio 2003). The limited number of studies conducted in polar regions, however, report consistently high bacterial rRNA content. Simon et al. (1999) found a detection rate in Southern Ocean waters that increased from 61 to $96 \%$ between the Polar Front and marginal ice zone, while Brinkmeyer et al. (2003) reported $~ 95 \%$ of cells in firstyear pack-ice in the Weddell Sea to be probe-positive, which compares well with our estimate of $80 \%$ for the Cape Hallett fast-ice community. Although a lower percentage of cells $(\sim 60 \%)$ were detected by Junge et al. (2004) in sea ice sampled during the Arctic winter, this is likely to reflect seasonal variation in bacterial activity (e.g. Pearce et al. 2007), and in general FISH detection rates appear to be significantly higher in sea ice than in other systems.

The probe that has been most widely used to assess single-cell activity is CTC, developed by Rodriguez et al. (1992). This technique has gained wide application in recent years in environmental studies and has been reported to be a simple and effective method of separating active from inactive bacteria, without the need for sophisticated equipment (Créach et al. 2003). Cells that reduce sufficient CTC to be scored as ETS-active are considered to be undergoing oxidative metabolism and capable of growth. Although some fraction of active cells may be misrepresented by the CTC assay, there is general agreement that this technique is useful to determine the most active cells in a natural population (Sherr et al. 2001, Davidson et al. 2004, Gasol \& Arístegui 2007). CTC-staining of bacteria in seawater has typically ranged from 2 to $10 \%$ (Gasol et al. 1995, Sherr et al. 1999, Sherr et al. 2002, Longnecker et al. 2005). To our knowledge CTC has been employed only twice before in polar ecosystems. Junge et al. (2002) 
found up to $27 \%$ of bacterial cells in Arctic pack-ice during the summer to be undergoing active respiration, but interestingly found only 0.5 to $4 \%$ activity during a manipulative experiment in winter (Junge et al. 2004). We present the first application of CTC in Antarctic sea ice, and findings are comparable with those of Junge et al. (2002) in the Arctic summer.

\section{CONCLUSION}

The findings presented here are considered preliminary given the small sample size, but do confirm sea ice to be a productive microbial habitat. Additionally, this data provides a useful calibration for future experiments, particularly in addressing factors that influence bacterial-algal linkages. Clearly, there are limitations inherent to each technique, but we favour CTC for single-cell experimental work in the sea ice system. The main advantage of CTC is that intracellular enzymatic activity responds more quickly than changes to cellular structures, and it seems unlikely that other assays can be used to quantify changes in metabolic activity in short-term experiments. Even if the assay targets only the most active bacterial fraction, we suggest that this response may be representative of overall sea ice community dynamics. In addition, CTC is a relatively easy assay to use in Antarctic field conditions, and flow cytometry provides a rapid and accurate means of sample processing.

Acknowledgements. We acknowledge the logistical support of Antarctica New Zealand and in particular S. Gordon, Project Manager of the Latitudinal Gradient Project (LGP). We thank M. H. Lee for advice on FISH. This research was funded in part by an Antarctica New Zealand/New Zealand Post scholarship and Victoria University of Wellington Postgraduate Scholarship for PhD Study awarded to A.M.; K.G.R acknowledges the support of the Foundation of Research, Science and Technology: contract numbers VICX0219 and VICX0706.

\section{LITERATURE CITED}

Alonso-Sáez L, Gasol JM, Lefort T, Hofer J, Sommaruga R (2006) Effect of natural sunlight on bacterial activity and differential sensitivity of natural bacterioplankton groups in northwestern Mediterranean coastal waters. Appl Environ Microbiol 72:5806-5813

Azam F, Worden AZ (2004) Microbes, molecules, and marine ecosystems. Science 303:1622-1624

Azam F, Smith DC, Hollibaugh JT (1991) The role of the microbial loop in Antarctic pelagic ecosystems. Polar Res 10:239-243

Bernard L, Courties C, Duperray C, Schäfer H, Muyzer G, Lebaron P (2001) A new approach to determine the genetic diversity of viable and active bacteria in aquatic ecosystems. Cytometry 43:314-321

Bouvier T, del Giorgio PA (2003) Factors influencing the detection of bacterial cells using fluorescence in situ hybridization (FISH): a quantitative review of published reports. FEMS Microbiol Ecol 44:3-15

Brinkmeyer R, Knittel K, Jurgens J, Weyland H, Amann R, Helmke E (2003) Diversity and structure of bacterial communities in Arctic versus Antarctic pack ice. Appl Environ Microbiol 69:6610-6619

Créach V, Baudoux AC, Bertu G, Le Rouzic B (2003) Direct estimate of active bacteria: CTC use and limitations. J Microbiol Methods 52:19-28

Davidson AT, Thomson PG, Westwood K, van den Enden R (2004) Estimation of bacterioplankton activity in Tasmanian coastal waters and between Tasmania and Antarctica using stains. Aquat Microb Ecol 37:33-45

> Delille D (1996) Biodiversity and function of bacteria in the Southern Ocean. Biodivers Conserv 5:1505-1523

Garrison DL, Gibson A, Coale SL, Gowing MM, Okolodkov YB, Fritsen HF, Jeffries MO (2005) Sea-ice microbial communities in the Ross Sea: autumn and summer biota. Mar Ecol Prog Ser 300:39?52

Gasol JM, Arístegui J (2007) Cytometric evidence reconciling the toxicity and usefulness of CTC as a marker of bacterial activity. Aquat Microb Ecol 46:71-83

> Gasol JM, del Giorgio PA, Massana R, Duarte CM (1995) Active versus inactive bacteria: size-dependence in a coastal marine plankton community. Mar Ecol Prog Ser 128:91-97

Giesenhagen HC, Detmer AE, de Wall J, Weber A, Gradinger RR, Jochem FJ (1999) How are Antarctic planktonic microbial food webs and algal blooms affected by melting of sea ice? Microcosm simulations. Aquat Microb Ecol 20: $183-201$

Grégori G, Citterio S, Ghiani A, Labra M, Sgorbati S, Brown S, Denis M (2001) Resolution of viable and membrane-compromised bacteria in freshwater and marine waters based on analytical flow cytometry and nucleic acid double staining. Appl Environ Microbiol 67:4662-4670

Howard-Jones MH, Frischer ME, Verity PG (2001) Determining the physiological status of individual bacterial cells. In: Paul J (ed) Methods in microbiology, Vol 30. Marine microbiology. Academic Press, London, p 175-206

Howard-Jones MH, Ballard VD, Allen AE, Frischer ME, Verity PG (2002) Distribution of bacterial biomass and activity in the marginal ice zone of the central Barent's Sea during summer. J Mar Syst 38:77-91

Joux F, Lebaron P (2000) Use of fluorescent probes to assess physiological functions of bacteria at single-cell level. Microbes Infect 2:1523-1535

- Junge K, Krembs C, Demming J, Stierle A, Eicken H (2001) A microscopic approach to investigate bacteria under in situ conditions in sea-ice samples. Ann Glaciol 33:304-310

Junge K, Imhoff F, Staley T, Deming JW (2002) Phylogenetic diversity of numerically important Arctic sea-ice bacteria cultured at subzero temperature. Microb Ecol 43:315-338

Junge K, Eicken H, Deming JW (2004) Bacterial activity at -2 to $-20^{\circ} \mathrm{C}$ in Arctic wintertime sea ice. Appl Environ Microbiol 70:550-557

Kottmeier ST, Sullivan CW (1988) Sea ice microbial communities IX. Effects of temperature and salinity on metabolism and growth of autotrophs and heterotrophs. Polar Biol 8: 293-304

Longnecker K, Sherr BF, Sherr EB (2005) Activity and phylogenetic diversity of bacterial cells with high and low nucleic acid content and electron transport system activity in an upwelling ecosystem. Appl Environ Microbiol 71: 7737-7749

Maranger R, del Giorgio PA, Bird DF (2002) Accumulation of 
damaged bacteria and viruses in lake water exposed to solar radiation. Aquat Microb Ecol 28:213-227

Nichols DS, Greenhill AR, Shadbolt CT, Ross T, McMeekin TA (1999) Physicochemical parameters for growth of the sea ice bacteria Glaciecola punicea ACAM $611^{\mathrm{T}}$ and Geldicacter sp. strain IC158. Appl Environ Microbiol 65: 3757-3760

Pearce I, Davidson AT, Bell EM, Wright S (2007) Seasonal changes in the concentration and metabolic activity of bacteria and viruses at an Antarctic coastal site. Aquat Microb Ecol 47:11-23

Pernthaler J, Glockner FO, Schonhuber W, Amann R (2001) Fluorescence in situ hybridization (FISH) with rRNA-targeted oligonucleotide probes. In: Paul J (ed) Methods in microbiology, Vol 30. Marine microbiology. Academic Press, London, p 207-226

Pernthaler A, Preston CM, Pernthaler J, DeLong EF, Amann R (2002) Comparison of fluorescently labeled oligonucleotide and polynucleotide probes for the detection of pelagic marine bacteria and archaea. Appl Environ Microbiol 68:661-667

Rodriguez GG, Phipps D, Ishiguro K, Ridgway HF (1992) Use of a fluorescent redox probe for direct visualization of actively respiring bacteria. Appl Environ Microbiol 58: 1801-1808

Ryan KG, Ralph P, McMinn A (2004) Acclimation of Antarctic bottom-ice algal communities to lowered salinities during melting. Polar Biol 27:679-686

Sherr BF, del Giorgio P, Sherr EB (1999) Estimating abundance and single-cell characteristics of respiring bacteria via the redox dye CTC. Aquat Microb Ecol 18:117-131

Editorial responsibility: Josep Gasol,

Barcelona, Spain
Sherr BF, Sherr E, del Giorgio PA (2001) Enumeration of total and highly active bacteria. Methods Microbiol 30:129-159

Sherr EB, Sherr BF, Verity PG (2002) Distribution and relation of total bacteria, active bacteria, bacterivory, and volume of organic detritus in Atlantic continental shelf waters off Cape Hatteras NC, USA. Deep-Sea Res II 49:4571-4585

Simon M, Glöckner FO, Amann R (1999) Different community structure and temperature optima of heterotrophic picoplankton in various regions of the Southern Ocean. Aquat Microb Ecol 18:275-284

Smith EM, del Giorgio PA (2003) Low fractions of active bacteria in natural aquatic communities? Aquat Microb Ecol $31: 203-208$

Stewart FJ, Fritsen CH (2004) Bacteria-algae relationships in Antarctic sea ice. Antarct Sci 16:143-156

- Sullivan CW, Palmisano AC (1984) Sea ice microbial communities: distribution, abundance, and diversity of ice bacteria in McMurdo Sound, Antarctica, in 1980. Appl Environ Microbiol 47:788-795

Sullivan CW, Palmisano AC, Kottmeier S, McGrath Grossi S, Moe R (1985) The influence of light on growth and development of the sea ice microbial community in McMurdo Sound. In: Siegfried WR, Condy PR (eds) Antarctic nutrient cycles and food webs. Springer-Verlag, Berlin, p78-83

Williams SC, Hong Y, Danavall DCA, Howard-Jones MH, Gibson D, Frischer ME, Verity PG (1998) Distinguishing between living and nonliving bacteria: evaluation of the vital stain propidium iodide and its combined use with molecular probes in aquatic samples. J Microbiol Methods $32: 225-236$

Submitted: May 19, 2007; Accepted: April 17, 2008

Proofs received from author(s): June 5, 2008 